\title{
Review
}

\section{Just liberal violence: Sweatshops, torture, war}

\author{
Michael Neu \\ Rowman \& Littlefield International, London, 2017, xi+149pp., \\ ISBN: 978-1-7866-0064-6
}

Contemporary Political Theory (2020) 19, S210-S213. https://doi.org/10.1057/s41296019-00317-z; Published online 1 April 2019

Michael Neu's Just Liberal Violence is a well-written and timely book that develops a new framework for evaluating alternative defences of liberal violence. It combines high intellectual precision with accessible language and could thus prove an important resource for a broad audience, be it activists fighting liberal violence, students new to moral and political philosophy, or distinguished contributors to the theoretical debates on violence. As part of the 'Off the Fence: Morality, Politics and Society' series, Neu's work presents a concise attempt at highlighting the common movements and strategies that make justifications of war, torture, and sweatshop labour not just problematic at a theoretical level; instead, they are shown to have a devastating effect on the world as they lend legitimacy to pervasive forms of violence. The book is therefore also an important reflection on intellectual complicity, which is the central topic of a concluding chapter that interpellates academics to take responsibility for the effect that theorising has on real-world actions and judgements.

The first part of the book centres on the theoretical framework. Chapter 1, aptly titled 'A Plea for Defiance', introduces the overall argument and normative thrust of the project and provides a chapter outline. The second chapter covers a schematic guide to the reductive strategies that legitimate liberal violence. This schema is then put to use in the second part of the book, through a critical analysis of theoretical debates on sweatshop labour, torture, and war. Chapter 3 engages representatively with Benjamin Powell and Matt Zwolinski to articulate the problematic justification of liberal violence in relation to sweatshop labour. Chapter 4 considers the theoretical framing of defences of torture, illustrated in dialogue with Fritz Allhof and Uwe Steinhoff, and the fifth chapter evaluates interventions by Michael Walzer and Jeff McMahan in just war theory, which similarly follow the reductive strategies identified in the first two chapters. Each chapter is informed by a sophisticated study of the difficult empirical contexts of sweatshop labour, torture, and war. The final chapter 6 turns to the complicity of

(C) 2019 Springer Nature Limited. 1470-8914 Contemporary Political Theory Vol. 19, S3, S210-S213 
the academic and uses Kazuo Ishiguro's Never Let Me Go imaginatively to articulate how these reductionisms engender violence even without reverting to the use of physical violence.

The book tackles forms of 'just liberal violence', by which Neu means theoretical defences of the use of violence to alleviate suffering and protect human rights that, on closer inspection, turn out to be nothing more than (liberal) violence (p. 1). Just Liberal Violence highlights that liberal defences of violence are beset by reductionisms, which can be summarised in relation to three concepts: violence, agency, and perspective. Due to these reductionisms, the violence of war, torture, and sweatshop labour becomes seemingly acceptable and necessary, on a certain liberal reading. Firstly, violence is reduced to direct acts of killing, particularly in just war theory, while structural and non-physical forms of violence are excluded. The consequence is that many of the ways in which liberal democracies cause violence, for example the economic costs of a foreign military intervention for the local population, are presented as inconsequential for assessing whether or not an activity is morally right or wrong. Secondly, agency is reduced in a number of problematic ways. Liberal defences of violence narrow the horizon of action, meaning that agents are only given the opportunity to act once the use of violence is all-but-inevitable. Torture is legitimated by the presupposition of an imminent threat and little discussion centres on means of preventing such a situation from occurring in the first place, or on suitable alternatives to either torturing or letting the terrorist attack happen. The liberal agent is cast in a tragic but heroic role and faces a binary set of moral choices, between good and evil, right and wrong. In making the 'right' choice, guided by moral theorising, the agent is able to retain their moral purity and to transcend the implications of wrongdoing. Thirdly, as a consequence of this reductive conception of agency, liberal defences of violence rely on a narrow perspective on the world. This perspective is encapsulated in the enticing prospect of gaining pure knowledge through thought experiments. Scholars use this epistemological tool to abstract from socio-political contexts. They assume that moral truth can be achieved by doing away with the inconveniences caused by the particulars of a specific case, seen as preventing rational judgements from identifying the uniquely morally right way of addressing an issue. The challenge of tackling injustice and violence becomes one of finding ever more abstract examples that can no longer be challenged by one's similarly minded colleagues. In short, Neu offers a robust rejection of the pervasive desire for apolitical theorising in moral and political philosophy.

The three reductionisms are framed by two foundational problems. Firstly, just liberal violence denies the interdependences characterising social reality. The key units of thought are the actions of atomised individuals who are de-contextualised and disembedded from the web of social relations. The defences embrace a vision of 'complete disconnectedness' (p. 16), which in turn enables the assertion that there is 'a nonviolent normality among the just and civilised, a state of affairs

(c) 2019 Springer Nature Limited. 1470-8914 Contemporary Political Theory Vol. 19, S3, S210-S213 S211 
regularly disrupted, from the outside, by irrational perpetrators of aggression' (p. 17). Secondly, the arguments for just liberal violence both reject political realism with its emphasis on fear, power, and domination, but they also (unintentionally) maintain the violent status quo. Defenders seek to transcend realism by opening the space for morally justifiable action and assume that realism is tied to uncivilised forms of violence that liberal regimes have successfully left behind. However, in carving out action and realist worldly conditions, just liberal violence obscures how the supposedly just action reproduces the violent status quo that political realism seeks to be sensitive to. The outcome is a 'moralistic realism' (p. 20) that merely advances moral tools and justifications to further violent means. In sum, the book goes against a liberal framework 'obsessed with individuals, blind to social hierarchies and interconnectedness, and fanatically fixated on pressing the complex material world into a binary moral structure of right and wrong' (p. 100).

The strength of the book lies in providing a clear and sophisticated means to identify the pernicious ways in which philosophising distorts the parameters of moral judgement and may hopefully serve as a key starting point for imagining new ways of thinking about violence. To this end, I would like to point out two ways in which this book could serve as a starting point to think further about the transformation of moral philosophising on liberal violence. Firstly, the book draws on a wide range of literature to mount its critique of just liberal violence and, naturally, not everything can be covered. Yet, there would have been much added value in engaging with existing critiques of the moralist framework, for example the substantive challenge to just war theory from a feminist perspective by, amongst others, Laura Sjoberg. These allied voices are instead relegated to a brief overview in a footnote. Engaging with this literature could have helped raise a number of important questions: Why do these reductive forms of thinking remain prevalent despite past criticisms? How can critical voices respond to the way challenges continue to be ignored in favour of a largely unchanged 'business-asusual' approach in applied ethics? Secondly, the book is not only a negative project dedicated to dismantling a problematic form of theorising. Neu also highlights ways in which theorists can navigate the difficult challenges posed by theorising violence without falling for the reductive strategies. The discussion of the complicity of the intellectual is key here, but remains too underdeveloped, instead leading to a tension at the heart of the book. Just Liberal Violence seems to fall back on critiquing theorists independently from their social context, and pays particular attention to the intellectual as to some extent a de-contextualised individual. This raises important questions about how to engage with a debate in political theory about violence, without reproducing the reductive premises that unduly privilege the position of the philosopher, and without obscuring the socioeconomic and especially academic institutions and practices that facilitate this form of theorising.

S212 (c) 2019 Springer Nature Limited. 1470-8914 Contemporary Political Theory Vol. 19, S3, S210-S213 
Both points allude to the complex, open-ended process of critiquing liberal philosophical practices. The book ultimately proposes that scholars take 'a step back' and reflect 'critically on the defects of their framework of analysis', so that we might be able to 'tackle a moral climate characterised by a pervasive amnesia about the histories, structures and politics of violence' (p. 100). In light of the questions I raised, this critical attitude may prove a significant, albeit in important ways limited, way forward. Instead, the strength of the book lies in providing a clear and sophisticated means to identify the pernicious ways in which philosophising distorts the parameters of moral judgement and may hopefully serve as a key starting point for imagining new ways of thinking about violence.

Publisher's Note Springer Nature remains neutral with regard to jurisdictional claims in published maps and institutional affiliations.

Gisli Vogler University of Edinburgh, Edinburgh EH8 9YL, Scotland, UK gvogler@exseed.ed.ac.uk 